\title{
Pyramiden - Häuser für die Ewigkeit
}

Ausstellung im Palmengarten vom 10. Mai bis 30. September 2007 in Zusammenarbeit mit der Universität Potsdam

Die Ausstellung erzählt die Entstehung und Geschichte der großen Pyramiden Ägyptens. Zahlreiche Modelle und Originalwerkzeuge geben Aufschluss über den Pyramidenbau. Die begehbare Rekonstruktion einer Grabkammer und die Darstellung der Lebensbedingungen dieser Zeit sind Höhepunkte dieser Ausstellung. Ursprüngliche Objekte aus dem alten Ägypten, wie Statuen und Dienerfiguren, Reliefs und Opfertafeln, führen uns in die Grabkultur und Jenseitsvorstellungen ein. Vom Barock an breitet sich die Ägyptomanie, die Begeisterung für das Land der Pyramiden, in ganz Europa aus. Die Ausstellung zeigt, wie sich ägyptisierende Motive - die Pyramide, der Obelisk und die Sphinx - als Elemente in der Gartenbaukunst oder im Porzellan etablieren. Fast alle gekrönten Häupter Europas - von NAPOLEON über KaISER
Franz Josef bis zum Herzog ERnst von SACHSEN-COBURG - bereisten Ägypten. Gedenkmünzen, Aquarelle und Stiche halten ihre Besuche fest und die Versuche, die Pyramiden von Gizeh $\mathrm{zu}$ besteigen.

Abb. 1: Ausschnitt aus der Wandbemalung eines begehbaren Modells einer Grabkammer im Maßstab 1:1.

Abb. 2 (S. 76, oben): Modelle verschiedener PyramidenBautypen.

Abb. 3 (S. 76, unten links): Kanope, Gießkeramik, Originale aus Kalzit-Alabaster; dritte Zwischenzeit bis Spätzeit, ca. 1000-500 v. Chr., Cottbus, Stiftung Fürst-PüCKLER-Museum, Park und Schloss Branitz.

Abb. 4 (S. 76, unten rechts): Uschebti, Fayence; Ptolemäerzeit, 3. Jh. v. Chr.; Hildesheim, Römer- und PelizaeusMuseum.

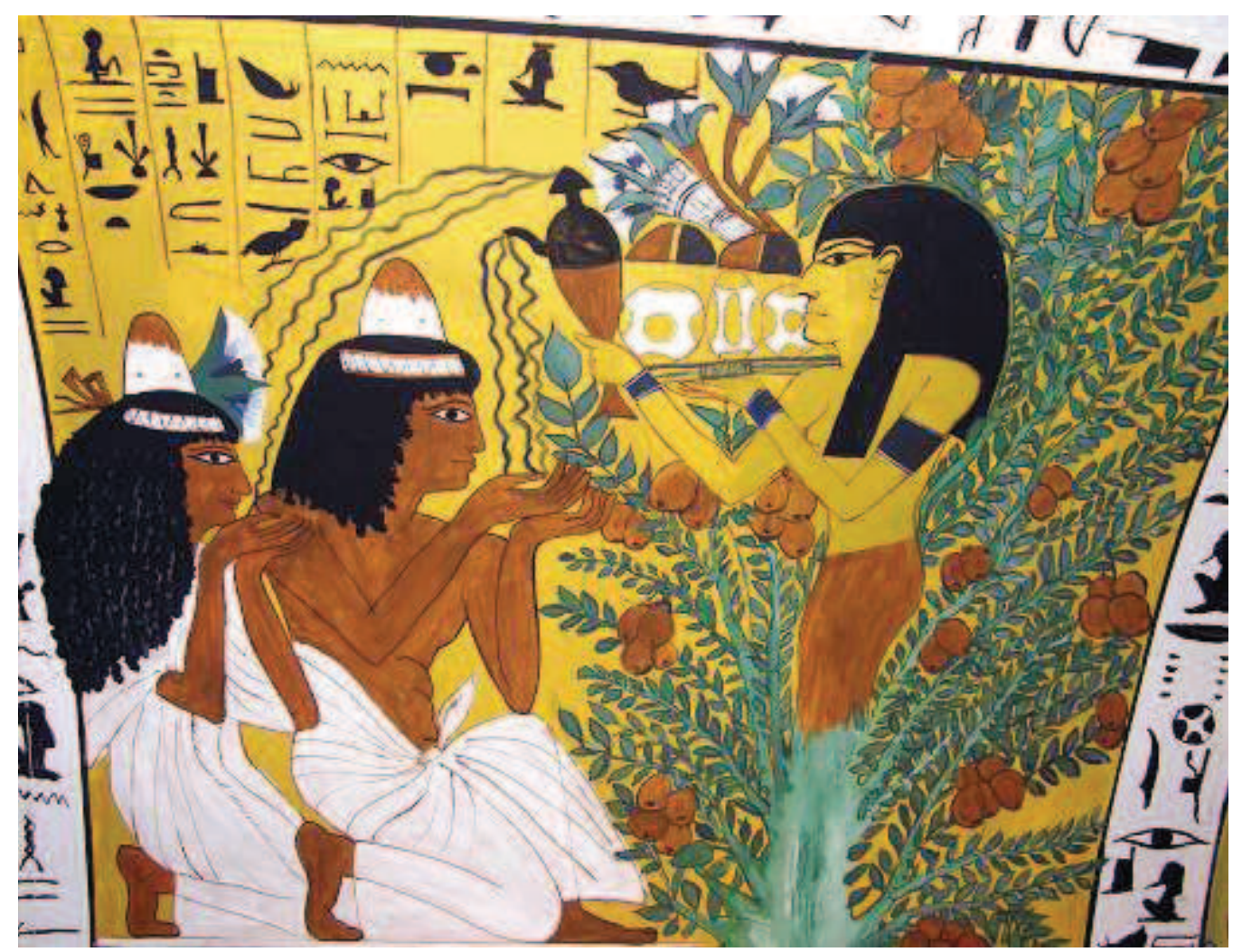



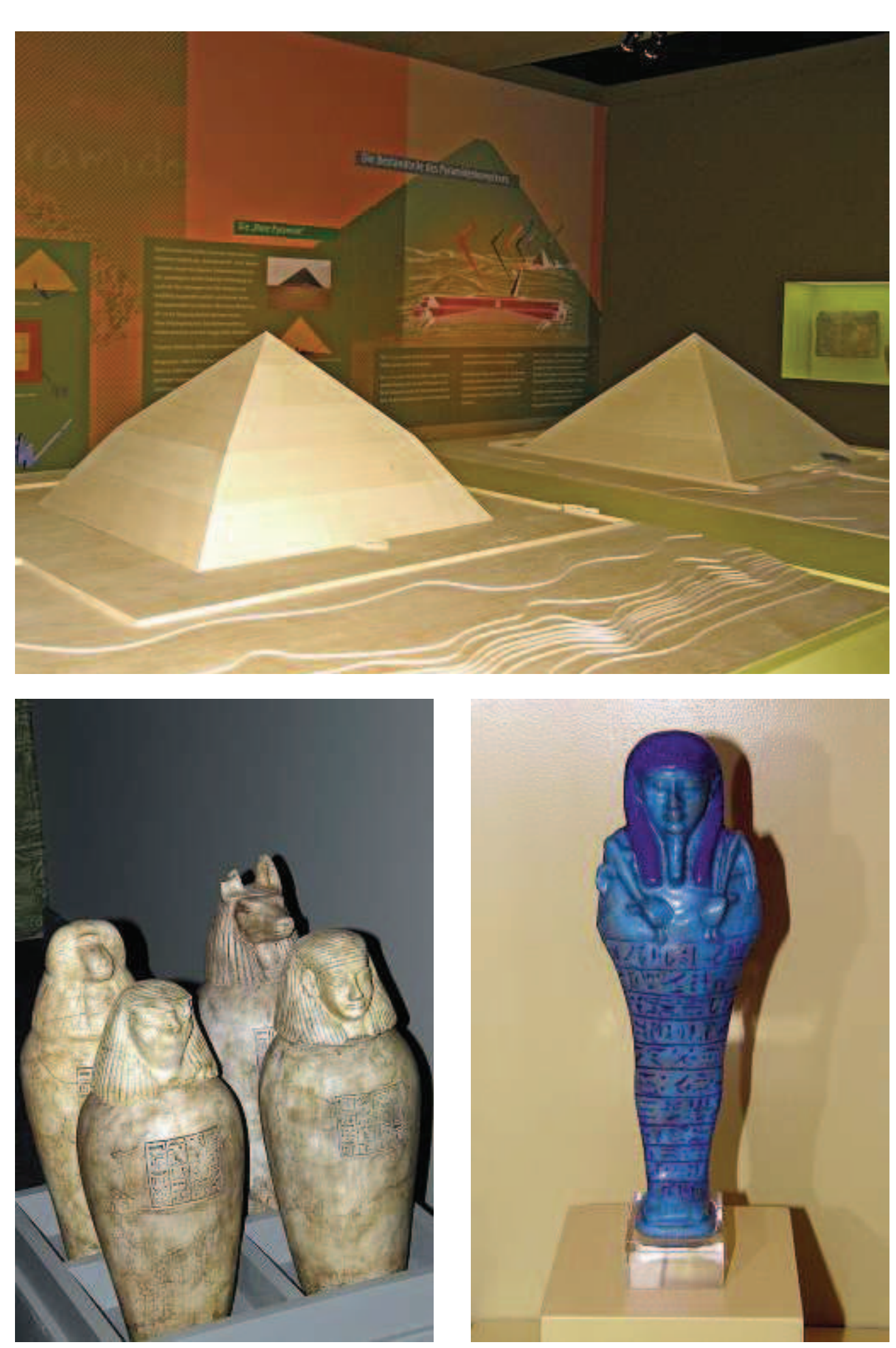